\title{
STUDENT PERCEPTION OF THE PRECEPTORSHIP MODEL IN MIDWIFERY CARE: A SCOPING REVIEW
}

\author{
Ana Dyah Aliza, Farida Kartini \\ Universitas ‘Aisyiyah Yogyakarta
}

\begin{abstract}
Background: Preceptorship is a time-limited, education-focused model for teaching and learning within a clinical environment that uses a clinical staff as role models. Its primary goal is to assist new staff and students in adapting to their roles, develop clinical skills and socialize the novice to a department or institution. This difference has caused various opinions from related parties. This study aimed to determine the implementation of a tutorial system from different levels of student education to the entire midwifery health care system.

Subjects and Method: A scoping review method was conducted in eight stages including (1) Identification of study problems; (2) Determining priority problem and study question; (3) Determining framework; (4) Literature searching; (5) Article selection; (6) Critical appraisal; (7) Data extraction; and (8) Mapping. The search included PubMed, Wiley, Google Scholar, dan Sciendirect. The inclusion criteria were English-language and full-text articles published between 2000 and 2019. The data were selected by the PRISMA flow chart.

Results: Ten articles from total of 803 articles found. It was divided into two categories: Elements in the preceptorship model and application of preceptorship. Preceptorship can help preceptors to improve teaching effectiveness and create an effective learning environment so that preceptors can perform clinical skills to improve the quality of education. The problem that arises in preceptorship in many student reports is the difficulty students experience in finding their clinical practice area. Professional organizations provide several solutions to the issues that occur in a preceptorship, one of which is paying attention to student attendance and facilitating students to give input and ideas.

Conclusion: The application of the principles in the practice of midwifery clinics varies because the guideline instruments are not standardized.
\end{abstract}

Keywords: Perspectives, Preceporship, Students, Midwifery

\section{Correspondence:}

Ana Dyah Aliza, Universitas 'Aisyiyah Yogyakarta. Jalan Ringroad Barat No.63, Mlangi, Nogotirto, Gamping Sleman, Yogyakarta, Email: anadyahaliza@gmail.com Mobile: 085600072744 . 